\title{
Operative Treatment of Femoral Neck Fractures with Cannulated Screws with and without Platelet Rich Plasma in Young Adults: A Comparative Study
}

\author{
Mohammed Sh. Al- Edanni ${ }^{1}$, Raed-A. Al Yaseen ${ }^{2}$, Ghadeer H. Majeed ${ }^{1}$, Sadik A. Al-Muktar ${ }^{1}$ \\ ${ }^{1}$ Al- KindyCollege of Medicine, University of Baghdad, Baghdad, Iraq \\ ${ }^{2}$ Al-Kindy Teaching Hospital, Ministry of Health, Iraq
}

\section{SUMMARY}

Many studies have evaluated the effect of platelet rich plasma (PRP) in the treatment of non-union fractures but few studies have investigated their effect on the union of femoral neck fractures or their functional outcome in young adults.

The aim of this study was to evaluate the union time and functional outcome in young adult patients with femoral neck fracture managed by three cannulated screws injected with PRP and those managed by fixation only.

This prospective study included 24 patients diagnosed with femoral neck fractures within 24 hours of presentation. Twelve cases in group A were managed by closed reduction and three cannulated screws fixation injected with PRP; twelve patients in group B were managed only by closed reduction and three cannulated screws fixation. Results revealed a significant difference between the two groups $(p=0.004)$ with regard to mean union time, (group A - 3.9 months, group B - 4.8 months). No statistically significant differences were found in functional outcomes between groups, as measured by the Harris Hip Score and Visual Analogue Scale.

Key words: PRP, the femoral neck fracture, cannulated screws

Corresponding author:

Mohammed Sh. Al-Edanni

E-mail: orthomohammed1970@yahoo.com 


\section{INTRODUCTION}

Hip fractures account for about $20 \%$ of all surgical traumatic operations presented to orthopedic trauma unit; half of them involve the neck femur. Worldwide, the prevalence is expected to increase from 1.66 million in 1990 to 6.26 million in 2050, due to the increases in life expectancy. The femoral neck fracture occur mainly in females with a female to male ratio of 2:1 (1).

About $15 \%$ of intracapsular fracture of femoral neck are displaced $(2,3)$, with the remainders being undisplaced and occurring predominantly in an elderly female patients. The management includes different options ranging from reduction and screws fixation, bipolar or unipolar hemiarthroplasty, to total hip arthroplasty (4, 5). However, about $35 \%$ of operated displaced fractures require revision surgery as a consequence of screw fixation failure (6), and any aide that can enhance fracture healing and reduce the rate of failure of fixation may have the potential impact on treatment outcomes.

Platelet-rich plasma (PRP) is an autologous blood product with supra-physiological high platelets percentage used since the early nineties in orthopedic surgery and aiming to increase and promote bone healing $(7,8)$. These products can be prepared by filtering or centrifugation of whole blood after mixing with an anticoagulant (9). This therapy has been used to accelerate healing, based on the leading role of platelets in the initiating the hemostatic process and wound healing phases, mainly by releasing growth factors and interleukins including IL-2, IL-8, tumor necrosis factor $\alpha$, platelet-derived growth factor (PDGF), transforming growth factor $\beta$ (TGF- $\beta$ ), and bone morphogenetic proteins (10).

Healing of the bone fracture is a complicated physiological process started after injury. It implicated the harmony between immune and hematopoietics cells within the bone marrow in coupling with vascular and skeletal cell precursors, including mesenchymal stem cells induction from the circulation and the surrounding tissues (11). Platelets perform a leading role in the initiating the hemostatic process and wound healing phases, releasing growth factors and intertokines including IL-2, IL-8, tumor necrosis factor a, platelet-derived growth factor (PDGF), transforming growth factor $b$ (TGF-b), and bone morphogenetic proteins.

The role of PRP in fracture neck femur is still scarce and controversial. To our knowledge, only Xavier L Griffin et al (3) showed no effect of PRP on fracture neck femur union in elderly, while Samy AM et al. (2) and Weihua Ren et al (1) showed that both the median clinical and radiographic healing time were lower in the group who added PRP to screw fixation. Good-quality evidence for platelet-rich therapy is still sparse clinically and the National Institute of Health and Clinical Excellence (NICE) in the United Kingdom has advised the application of PRP to fracture site to enhance healing (12). One exciting area of research referred to increased healing in osteoporotic fractures (13). Fractures neck femur is the best example. Failure of internal fixation to treat these hip fractures is common, reaching to onethird of displaced fracture requiring revision surgery. Therefore, any adjunctive therapy that can increase fracture healing and decrease the rate of fixation failure is important for patient care and prognosis. The use PRP is one of these method therapies $(11,14,15)$.

\section{AIMS}

The aim of the study was to show the possibility of any beneficial outcome of using PRP as an adjunct in young adult femoral necks fractures treated by cannulated screws, involving union time and functional outcome.

\section{PATIENTS AND METHODS}

Patients admitted to the Orthopedic and Trauma Department of Alkindy teaching hospital Baghdad, Iraq, from October 2016 to October 2017, were enrolled in the present study. They met the following inclusion criteria:

1. Patients were aged from 20 to 45 years.

2. They were operated within 24 hours from sustaining an injury.

3. Having isolated injury.

In addition, patients with Garden IV, chronic disorders, pathological or opened fractures were excluded. Finally, eligible patients were allocated sequentially into one of two groups: the first group (group A) was managed by operative fixation with closed reduction and internal fixation by 3 cannulated screws with PRP, whereas the second group (group B) was managed by operative fixation with closed reduction and internal fixation by 3 cannulated screws without PRP.

Informed consent was obtained from all patients.

Proper detailed medical history and clinical examination were performed in all patients including antero-posterior (AP) pelvic radiographs with a full length of the ipsilateral femur as well as inclusion of the uninjured hip. Lateral radiographs of the hip joint were taken to define the displacement of the femoral neck fracture. When the diagnosis was suspicious, the patients under- 
went magnetic resonance imaging or computed tomography.

Operative treatment included preanesthetic check-up with routine investigations and prophylactic antibiotic (Vancomycin $1 \mathrm{~g}$ in $200 \mathrm{cc}$ of normal saline) given 1 hour before induction. The patients were positioned in the supine position on a fracture table with good padding of both lower limbs. The fracture was evaluated by fluoroscopy before draping to ensure good AP and lateral views of the femoral neck before reduction. Reduction was done under fluoroscopy by traction with the hip held at 45 degrees of flexion and slight abduction; it was slowly brought in extension and internal rotation, and the involved limb was prepared and draped.

Initially, PRP was prepared by drawing $15 \mathrm{cc}$ of blood from the patient's cephalic or median cubital vein using a 20 cc syringe with anticoagulant tube under aseptic conditions. The blood was then put into a special PRP tube and centrifuged for 10 minutes with a soft spin, and then for another 10 minutes with a hard spin in order to prepare the PRP concentration for injection into the screws once they were inserted and reached the fracture site.

A skin incision was made, and the tensor fascia lata and vastus lateralis were incised and retracted anteriorly. A guide pin for cannulated screws was placed. Guide pins were checked by fluoroscopy using both AP and lateral views to ensure that the pins were $25 \mathrm{~mm}$ from the subchondral bone. The Garden index (16) was used to confirm the reduction in both AP and lateral views on fluoroscopy; an accepted reduction was required to be within 155 to 180 degrees in both the AP and lateral views.

The appropriate size screw for the inferior guide pin was inserted. Once the threads reached the fracture site, the guide pin was removed, and 1 cc of PRP was injected using a 22 gauge spinal needle. The guide pin was reinserted, and the screw was fully seated so the threads crossed the fracture site. A similar technique was used to insert the other two screws. The final position of screws was confirmed by fluoroscopy (Figure 1).
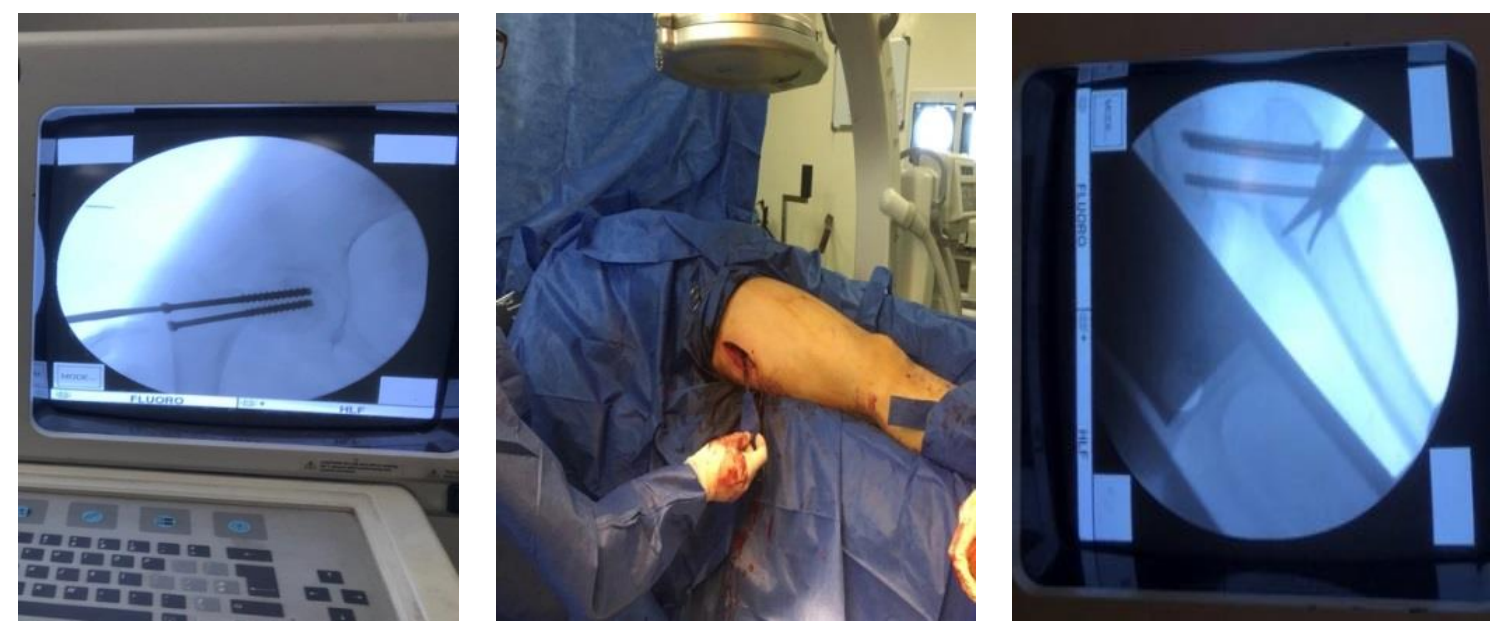

Figure 1. Insertion of cannulated screws

Irrigation was performed with 11 of normal saline and $160 \mathrm{mg}$ of gentamycin. A drain was not inserted. Closure of the fascia lata and the subcutaneous tissue was accomplished using absorbable 1 vicryl sutures. The skin was closed with interrupted 1 nonabsorbable nylon sutures. Finally, a dressing of sterile packs and adhesive plaster was applied. Patients were encouraged to leave their beds postoperatively as soon as possible; ambulation was started the day after surgery, and patients were allowed to walk without aids and without weight bearing during the first six weeks. Patients were asked to come to hospital 10-14 days postoperatively for the removal of stiches and were followed up at 4, 6 weeks, and every $2 \mathrm{~m}$ months hereafter for the follow-up of the fracture union rate, having checked the wound and radiographs. Exercises started 3 to 5 days postoperatively with hip abduction and adduction, hip and knee flexion, internal and external rotation of the quadriceps, and 
straight leg raise. After union was achieved, patients were instructed to gradually increase loading on the limb.

For all patients, postoperative management includes receiving of low molecular weight heparin (clexan $2000 \mathrm{IU}$ ) as a prophylaxis for deep venous thrombosis, antibiotics and analgesic. Thereafter, patients were followed up for 2, 4, and 6 weeks, 3 and 6 months postoperatively and the following parameters were assessed:

1. The time necessary for functional recovery: pain-free movements as measured with a visual analogue scale (VAS) (17).

2. The time necessary for fracture healing (radiographic union), as advised by radiologist.

3. A range of motion of the hip joint using the Harris Hip Score (HHS) (18).

4. Specific complication (nonunion, avascular necrosis (AVN), infection and hardware failure).

\section{Statistical analysis}

A Student's t-test was done, using SPSS to determine statistical differences. P-value $\leq 0.005$ denoted a highly significant difference.

\section{RESULTS}

During the period starting from October 2016 to October 2017, 68 patients with a femoral neck fracture were admitted to the Orthopedic Department of Al-kindy Teaching Hospital in Baghdad City, Iraq. Only 24 patients were eligible and enrolled in the study, being divided into two groups: the first group (group A) consisted of 12 patients (10 men and 2 women) managed by operative fixation with closed reduction and internal fixation by three cannulated screws with PRP, whereas the second group (group B) was composed of 12 patients (9 men and 3 women) managed by operative fixation with closed reduction and internal fixation by three cannulated screws without PRP.

The mean age of the patients in group $\mathrm{A}$ was 32.25 years ( 10 men and 2 women). In group B, the mean age of the patients was 33.25 years ( 9 men, and 3 women). There were significant differences between the proportion of men and women in the two groups (Table $1)$.

The mechanism of injury in all patients was road traffic accidents in 9 patients, 16 patients were drivers, 7 patients were passengers, and 1 patient was a pedestrian. In 15 patients, the affected femoral neck fracture was on the right side, and in 9 patients the affected femoral neck fracture was on the left side (Table 1).

In this study, the Garden classification system was applied. Nine patients were classified as Garden type I, 10 as Garden type II, and 5 as Garden type III (Table 1).

All patients in both groups were operated by the direct lateral approach with closed reduction and three cannulated screws, using an inverted triangle pattern. The patients in group A were injected with 3 cc of PRP at the fracture site.

At the end of the follow-up period, two patients in group B had non-union and AVN of the femoral head. In both cases, Garden type III was determined, and the patients were scheduled for total hip replacement later.

The HHS was developed to assess the results of hip surgery and was intended to evaluate various hip disabilities and methods of treatment in an adult population. The mean union time was 3.9 months in group A and 4.8 months in group B. There was a slight clinical difference between both groups (88.75 for group A, and 82.5 for group B).

The VAS is a criterion of pain intensity. There was no clinical difference between both groups ( 2.1 and 2.3 for groups A and B, respectively).

The VAS an HHS were evaluated at the time of surgery and at 6 months postoperatively. The statistical difference between the groups was evaluated at the end of the follow-up. There was a slight difference in functional HHS - 88.75 in group $\mathrm{A}$, and 82.5 in group $\mathrm{B}, \mathrm{P}=$ 0.03 , and the union time was highly significantly different between group A and group B - 3.9 months vs. 4.8 months. $(\mathrm{P}=0.004)$ (Table 2).

The complications in group A included wound infection in two patients, urinary tract infection in one patient, blood transfusion in one patient, deep vein thrombosis in one patient and pneumonia in one patient.

The complications in group B included wound infection in three patients, urinary tract infection in four patients, blood transfusion in one patient, deep vein thrombosis in two patients, hardware failure in one patient and pneumonia in two patients.

The three cases of deep venous thrombosis were diagnosed by Doppler study and treated by our cardiovascular surgeon. The 3 cases of pneumonia were diagnosed and treated by a respiratory medicine specialist (Table 3). 
Table 1. Patient distribution according to age, sex, injured side, mechanism of injury, smoking status and Garden classification

\begin{tabular}{llll}
\hline \hline \multirow{2}{*}{ Data } & & Group A & Group B \\
Mean age range(years) & & 32.25 & $\mathrm{n}=12(\%)$ \\
\hline \multirow{2}{*}{ Sex } & Male & $10(83.3)$ & 33.25 \\
& Female & $2(16.6)$ & $9(75)$ \\
\hline \multirow{2}{*}{ Injured side } & LT & $8(66.6)$ & $3(25)$ \\
\hline \multirow{2}{*}{ Mechanism of injury } & RT & $4(33.3)$ & $7(5 \mathrm{t} 8.3)$ \\
& RTA & 12 & $5(41.6)$ \\
& Passenger & $2(16.6)$ & 12 \\
& Pedestrians & $1(8.3)$ & $7(58.3)$ \\
\hline Smoking status & & $7(58.3)$ & $5(41.6)$ \\
\hline \multirow{2}{*}{ Garden classification } & Type II & $5(41.6)$ & $0(0)$ \\
\cline { 2 - 4 } & Type III & $3(25)$ & $5(46.6)$ \\
\hline \hline
\end{tabular}

Table 2. Functional outcome for both groups after six months

\begin{tabular}{lccc}
\hline \hline & $\begin{array}{c}\text { Group A } \\
\mathrm{n}=12\end{array}$ & $\begin{array}{c}\text { Group B } \\
\mathrm{n}=12\end{array}$ & P value \\
Radiographic non-union & 0 & 2 & - \\
Time of union (months) & 3.9 & 4.89 & 0.004 \\
HHS* & 88.75 & 82.5 & 0.03 \\
VAS $^{* *}$ & 2.1 & 2.3 & 0.11 \\
\hline \hline
\end{tabular}

*HHS= Harris Hip Score

**VAS= visual analogue score 
Table 3. Complications in both groups

\begin{tabular}{lccc}
\hline \hline & $\begin{array}{c}\text { Group A } \\
\mathrm{n}=12\end{array}$ & $\begin{array}{c}\text { Group B } \\
\mathrm{n}=12\end{array}$ & P value \\
Wound infection & 2 & 3 & - \\
Urinary tract infection & 1 & 4 & - \\
Blood transfusion & 1 & 1 & - \\
Deep vein thrombosis & 1 & 2 & - \\
Hardware failure and nonunion & 0 & 2 & - \\
Pneumonia & 1 & 2 & - \\
Total & 6 & 14 & 0.056 \\
\hline \hline
\end{tabular}

\section{DISCUSSION}

Hip fractures are common and comprise $20 \%$ of the operative workload of an orthopedic trauma unit. Intracapsular femoral neck fractures account for $50 \%$ of all hip fractures (1). The estimated annual cost of treating these fractures is enormous, being a significant burden to any health care system. There is very little debate about the management of the undisplaced intracapsular hip fracture, which is almost invariably treated with fixation. However, only $15 \%$ of these fractures are undisplaced $(2,3)$. There is still a surprising degree of variation in treatment; options include reduction and fixation, unipolar arthroplasty, bipolar hemiarthroplasty, and total hip arthroplasty $(4,5)$. However, a number of randomized trials have been published, which have provided better evidence on which to base treatment choices (19-22).

Platelet-rich plasma therapies have been used in the orthopedic surgery since early nineties (7), aiming to increase and promote both the soft tissue and bone healing (8).

We used platelet-rich plasma therapies in this study concomitant with screws fixation of femoral neck fracture to evaluate its effect on union time of the fractures and functional outcome.

The functional outcomes for all patients were measured six months after surgery. The mean time for fracture healing (radiologic union) was shorter in group A (mean $=3.9$ months) than in group B (mean $=4.8$ months). Thus, our results are in agreement with those of Weihua Ren et al. (1) who found a meantime for fracture healing of 3.37 months in surgically treated patients who received PRP and 4.56 months in patients without PRP. In addition, our study demonstrated the results similar to that of a study of the Orthopedic Department of Tanta University. In that study, Samy et al. (2) reported that the mean time to radiographic union was 3.55 months for the surgically treated patients receiving PRP and 4.23 months in operative patients without PRP. They also reported a marked decrease in the non-union rate for the operative group with PRP (6.7 \%) as compared with those without PRP (16.6 \%). Another study by Griffin et al. (3) found no evidence of a difference in the risk of revision surgery within one year between participants treated with platelet-rich therapy and those not treated, and there was no disparity in the development of non-union between both groups.

In our study, the following complications in group A were wound: infection (2 cases, $16.6 \%$ ), urinary tract infection (1 case - $8.3 \%$ ), blood transfusion (1 case $8.3 \%$ ), deep venous thrombosis ( 1 case $-8.33 \%$ ) and pneumonia (1 case $-8.3 \%$ ). The complications in group B were wound infection ( 3 cases - $25 \%$ ), urinary tract infection (4 cases- $-33.33 \%$ ), blood transfusion (1 case $8.3 \%$ ), deep vein thrombosis ( 2 cases $-16.6 \%$ ), pneumonia (2 cases - $16.6 \%$ ) and hardware failure (1 case $8.3 \%)$.

In our study, the complications were about the same as reported by Weihua Ren et al. (1), who reported three non-unions in the operative group with PRP compared with one non-union in the operative group with- 
out PRP. Most complications in the operative group with PRP were pneumonia (6 patients), urinary tract infection (4 patients), and deep vein thrombosis (2 patients).

With regard to functional outcomes in our study, there was a slight difference in both HHS and VAS between both groups. In group (A), the mean HHS was 88.75 and the VAS was 2.1, whereas in group B the mean HHS was 82.5 and the VAS was 2.3, and this parallels the study of Weihua Ren et al. (1) in which the values of HHS and VAS were 90.1 and 1.8, respectively in the operative group with $\mathrm{PRP}$, while in the operative group without PRP, the values of HHS and VAS were 89.8 and 1.9, respectively. Samy AM et al. (2) showed a similar result, while Griffin XL et al. (3) showed no effect of PRP on the femoral neck fracture in elderly regarding union and functional outcome.

\section{CONCLUSION}

Closed reduction and fixation of femoral neck fracture with PRP result in a significant decrease in union time. However, there was no difference among the groups in functional outcome as measured by the HHS and VAS.

\section{Recommendations}

We recommend further studies to evaluate the effect of PRP on bone healing, using a large sample and with one type of fracture at a time to rule out the effect of different fracture types on the whole sample. 


\section{References}

1. Weihua Ren, Fengchun Wang, Lei Sun, et al. Role of autologous platelet-rich plasma in the treatment of femoral neck fractures, JCEM 2016 ISSN: 19405901/IJCEM0023518

2. Samy AM. The role of platelet-rich plasma in the management of fracture neck femur: new insights. In tOrthop 2016; 40: 1019-24.

https://doi.org/10.1007/s00264-015-2844-1

3. Griffin XL, Achten J, and Parsons N, et al. Plateletrich therapy in the treatment of patients with hip fractures: a single Centre, parallel group, participantblinded, randomized controlled trial. BMJ Open 2013;3:e002583.doi:10.1136/bmjopen-2013- 002583 https://doi.org/10.1136/bmjopen-2013-002583

4. Singer BR, McLauchlan GJ, Robinson CM, et al. Epidemiology of fractures in 15,000 adults: The influence of age and gender. J Bone Joint Surg Br 1998; 80 (2):243-8.

https://doi.org/10.1302/0301-620X.80B2.7762

5. Dennison E, Mohamed MA, Cooper C. Epidemiology of osteoporosis. Rheum Dis Clin North Am 2006; 32 (4):617-29.

https://doi.org/10.1016/j.rdc.2006.08.003

6. Lu-Yao GL, Keller RB, Littenberg B, et al. Outcomes after displaced fractures of the femoral neck. A meta-analysis of one hundred and six published reports. J Bone Joint Surg Am 1994; 76:15-25. https://doi.org/10.2106/00004623-199401000-00003

7. Hall M, Band P, Meislin R. Platelet-rich plasma: current concepts and application in sports medicine. J Am Acad Orthop Surg 2009;Oct;17(10):602-8 https://www.ncbi.nlm.nih.gov/pubmed/19794217

8. Alsousou J, Thompson M, Hulley P, et al. The biology of platelet-rich plasma and its application in trauma and orthopedic surgery: a review of the literature. J Bone Joint Surg Br 2009; 91:987-96. https://doi.org/10.1302/0301-620X.91B8.22546
9. Intini G. The use of platelet-rich plasma in bone reconstruction therapy. Biomaterials 2009; 30:4956-66. https://doi.org/10.1016/j.biomaterials.2009.05.055

10. Redler LH, Thompson SA, Hsu SH, et al. Plateletrich plasma therapy: a systematic literature review and evidence for clinical use. Phys Sports Med 2011; 39:42-51.

https://doi.org/10.3810/psm.2011.02.1861

11. Parker MJ, Khan RJK, Crawford J, et al. Hemiarthroplasty versus internal fixation for displaced intracapsular hip fractures in the elderly. A randomized trial of 455 patients. J Bone Joint Surg Br 2002; 84:1150-5.

https://www.ncbi.nlm.nih.gov/pubmed/12463661

12. Interventional procedure overview of autologous blood injection for tendinopathy. NICE interventionnal procedures guidance 2008 .

13. Nauth A, Miclau T, Bhandari M, et al. Use of osteobiologics in the management of osteoporotic fractures. J Orthop Trauma 2011; 25 (Suppl 2):S51-5. https://doi.org/10.1097/BOT.0b013e31821b8c52

14. Lu-Yao GL, Keller RB, Littenberg B, et al. Outcomes after displaced fractures of the femoral neck. A meta-analysis of one hundred and six published reports. J Bone Joint Surg Am 1994; 76:15-25. https://doi.org/10.2106/00004623-199401000-00003

15. Parker MJ, Raghavan R, Gurusamy K. Incidence of fracture-healing complications after femoral neck fractures. ClinOrthopRelat Res 2007; 458:175-9. https://doi.org/10.1097/BLO.0b013e3180325a42

16. Charles M. Court-Brown, MD, FRCS Ed (Orth)James D. Heckman MD Margaret M. McQueen, MD, FRCS Ed (Orth) William M. Ricci, MD Paul Tornetta III, MD, femoral neck fractures, John F. Keating, Rockwood and Green's Fractures in Adult $8^{\text {th }}$ edition, Philadelphia, Wolters Kluwer Health 2015, 2043. 
17. Freyd, M.: The graphic rating scale. J. Educ. Psychol 14 83-102 (1923) https://doi.org/10.1037/h0074329

18. Harris WH. Traumatic arthritis of the hip after dislocation and acetabular fractures: treatment by mold arthroplasty. An end-result study using a new method of result evaluation. J Bone Joint Surg Am 1969 Jun; 51(4):737-55

https://doi.org/10.2106/00004623-196951040-00012

19. Bhandari M, Devereaux PJ, Tornetta P III, et al. Operative management of displaced femoral neck fractures in elderly patients. An international survey. J Bone Joint Surg Am 2005; 87(9):2122-30. https://doi.org/10.2106/JB]S.E.00535
20. Crossman PT, Khan RJ, MacDowell A, et al. A survey of the treatment of displaced intracapsular femoral neck fractures in the UK. 2002; 33(5):383-6. https://doi.org/10.1016/S0020-1383(02)00002-5

21. Iorio R, Schwartz B, Macaulay W, et al. Surgical treatment of displaced femoral neck fractures in the elderly: A survey of the American Association of Hip and Knee Surgeons J Arthroplast. 2006; 21(8): 1124-33.

https://doi.org/10.1016/j.arth.2005.12.008

22. Laursen JO. Treatment of intracapsular fractures of the femoral neck in Denmark: Trends in indications over the past decade. ActaOrthop Belg. 1999; 65(4): $478-84$. 


\title{
Operativno lečenje preloma vrata butne kosti primenom kanuliranih zavrtnja sa i bez ubacivanja plazme obogaćene trombocitima kod mlađih osoba: komparativna studija
}

\author{
Mohammed Sh. Al- Edanni' ${ }^{1}$ Raed-A. Al Yaseen², Ghadeer H. Majeed ${ }^{1}$, Sadik A. Al-Muktar ${ }^{1}$
}

\author{
${ }^{1}$ Medicinski koledž Al- Kindy, Univerzitet u Bagdadu, Bagdad, Irak \\ ${ }^{2}$ Bolnica Al-Kindy, Ministarstvo zdravlja, Irak
}

\section{SAŽETAK}

Do sada je u velikom broju studija ispitivan efekat primene plazme obogaćene trombocitima u lečenju nesraslih fraktura, ali je u malom broju studija ispitivan njen efekat na srastanje fraktura vrata butne kosti ili funkcionalni ishod kod mladjih osoba.

Cilj ove studije bilo je određivanje vremena srastanja frakture i funkcionalnog ishoda kod mlađih pacijenata sa prelomom vrata butne kosti, fiksiranim kanuliranim zavrtnjima kroz koje se ubacuje plazma obogaćena trombocitima i pacijenata kod kojih je urađena samo fiksacija.

Ova prospektivna studija je uključila 24 bolesnika kod kojih je dijagnostikovan prelom vrata butne kosti u okviru od 24 sata nakon dolaska na kliniku. Dvanaest fraktura u grupi A je bilo lečeno zatvorenom redukcijom i fiksacijom ubacivanjem tri kanulirana zavrtnja i plazme obogaćene trombocitima. Dvanaest bolesnika u grupi B je je bilo lečeno samo zatvorenom redukcijom i fiksacijom kanuliranim zavrtnjima. Rezultati su ukazali na značajnu razliku između ove dve grupe $(\mathrm{p}=0.004) \mathrm{u}$ pogledu vremena srastanja frakture (grupa $\mathrm{A}-3,9$ mesesci, grupa B - 4,8 meseci). Nije utvrđena statistički značajna razlika u fukcionalnom ishodu između grupa, što je utvrđeno Harris Hip Score-om i vizuelno-analognom skalom.

Ključne reči: plazma obogaćena trombocitima, prelom vrata butne kosti, kanulirani zavrtnji 